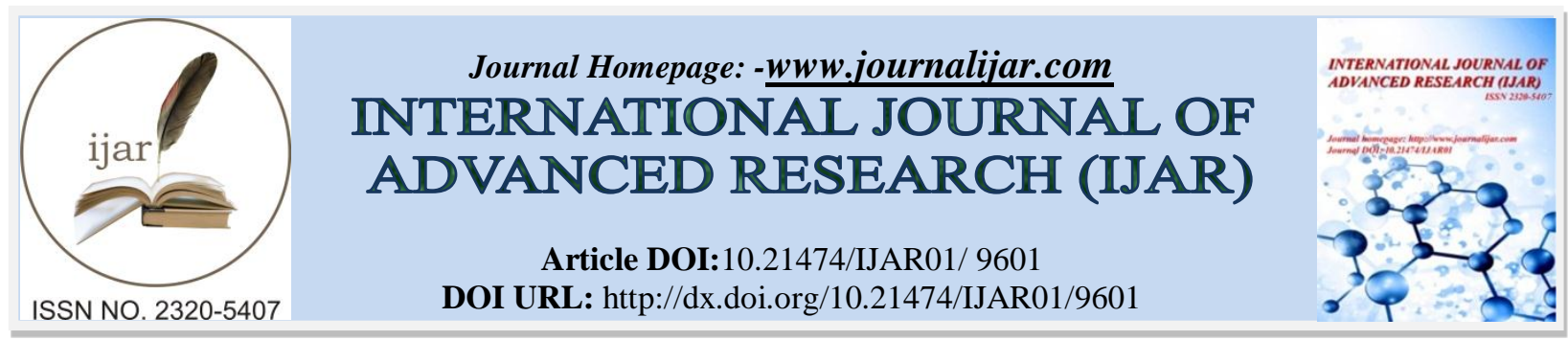

RESEARCH ARTICLE

\title{
SENIOR NURSING STUDENTS KNOWLEDGE TOWARD PEDIATRIC BASIC LIFE SUPPORT IN MIDDLE EUPHRATES OF IRAQ.
}

\author{
Noora Farhan Hassan ${ }^{1}$, Maha Salah Razzaq ${ }^{2}$ and Thikra Abdulkadhim ${ }^{3}$. \\ Faculty of Nursing / University of Kufa, Iraq.
}

\section{Manuscript Info}

\section{Manuscript History}

Received: 20 June 2019

Final Accepted: 22 July 2019

Published: August 2019

Key words:-

Senior Nursing Students, Knowledge, Pediatric Basic Life Support.

\section{Abstract}

Objectives:To assess senior nursing students' knowledge regarding pediatric basic life support; to find out association between students' knowledge and socio-demographic data.

Methodology: A descriptive design cross-section study was carried out at college of nursing in Middle Euphrates, from January 2019 until March 2019.

Results: The findings of present study indicate that the $(\mathbf{6 5 . 2} \%)$ from the study sample have incorrect knowledge about pediatric basic life support; non-significant association between student's knowledge about pediatric basic life support with socio-demographic data.

Conclusion: Regarding to overall assessment of student knowledge, most of them have poor knowledge about pediatric basic life support. The mass media is the main source of student knowledge about pediatric basic life support.

Recommendations: Pediatric basic life support should be considered as a part of nursing academic curriculum; Education program for nursing students to increase their knowledge about pediatric basic life support.

\section{Introduction:-}

Basic life support (BLS) refers to maintaining the airway and supporting breathing and circulation without equipment using. It is a technique necessary to keep a child alive in a life-threatening situation until the arrival of medical assistance. Every year, a number of children undergo with an severe illness enough to stop their breathing and leads to respiratory arrest, accident, trauma. The best option of ensure their survival is to give them an urgent management known as Basic life support or cardiopulmonary resuscitation. ${ }^{(1)}$

It is a series of events should be taken to try to revive a collapsed baby. BLS can be performed by everybody trained to do, and in anywhere. It is started as soon as when the child require it. There are basic points in Basic life support involve ABC: Airway, Breathing, and Circulation. ${ }^{(2)}$

Basic life support for children differs in several significant ways from adults and so requires specific instruction or training for performing. The mostly important difference is that basic life support for children is required for a respiratory or breathing emergency. This means that the majority of children, we must begin basic life support as soon as possible may require only the breathing part to be given, when heart will not be mainly affected. ${ }^{(3)}$ 
However, when damage occur in the brain and other essential organs such as heart muscle and kidneys begin to occur only a few minutes after hypoxia, it is essential that basic life support should be started immediately as soon as possible. Therefore, anyone suspected that the baby is not breathing adequately should be able to assessment the need for, and initiate BLS without any delay. ${ }^{(4)}$

In children there are some sudden causes of heart attack include: respiratory disorders such as airway obstruction, infection, trauma, , sudden infant death syndrome, poisoning and drowning. In United States the cardiac arrest may be occur suddenly outside the hospital about 400,000 /every year, with $90 \%$ mortality rate in children. ${ }^{(\mathbf{5})} ;{ }^{(\mathbf{6})}$

Knowledge and simple practice techniques about basic life support that increase the chances of children surviving until experienced medical staff assistance arrives. ${ }^{(7)}$

\section{Statement of problem:}

Senior Nursing Students Knowledge toward Pediatric Basic Life Support in Middle Euphrates of Iraq

1. To assess senior nursing students knowledge regarding pediatric basic life support.

2. To find out association between student's knowledge and selected variable.

\section{Design of the study:}

A descriptive design cross sectional study was adopted in the present study to achieve the objectives. The study started from February 2019 until March 2019.

\section{Setting of the study:}

the study was carried out in nursing colleges in the Middle Euphrates including (Najaf, Karbala, Diwaniyah, Babil and AL- Muthanna).

\section{Sample of the study:}

A randomized (simple random sample) of the study consists from 200 senior nursing students from colleges of nursing in middle Euphrates.

\section{Results:-}

Table 1:-Demographic characteristics of the study sample

\begin{tabular}{|l|l|l|l|}
\hline Groups & Frequency & Percentage \\
\hline \multirow{4}{*}{ Age (years) } & $20-22$ & 97 & 48.5 \\
\cline { 2 - 4 } & $23-25$ & 94 & 47 \\
\cline { 2 - 4 } & $\geq 26$ & 9 & 4.5 \\
\hline \multirow{3}{*}{ Gender } & Male & 78 & 39.0 \\
\cline { 2 - 4 } & Female & 122 & 61.0 \\
\hline \multirow{2}{*}{ Fesidence } & Rural & 147 & 73.5 \\
\cline { 2 - 4 } & Urban & 53 & 26.5 \\
\hline & Nuclear & 107 & 53.5 \\
\cline { 2 - 4 } & Extended & 93 & 46.5 \\
\hline
\end{tabular}

$$
\text { N (200) = Sample Size. }
$$

This table shows that demographic characteristics for participants. About (48.5\%) from them within age group (2022) years. Regarding to participant's gender, (61\%) of them is female. Concerning the residences area, the highest percentage from them living in the rural area. In regard to type of family, $(53.5 \%)$ of them lived with nuclear families.

Table 2:-Sources of student information about pediatric basic life support

\begin{tabular}{|l|l|l|l|}
\hline Items & Rating and intervals & Frequency & $\%$ \\
\hline \multirow{2}{*}{$\begin{array}{l}\text { Are you receiving information about } \\
\text { pediatric basic life support? }\end{array}$} & Yes & 114 & 57.0 \\
\cline { 2 - 5 } Total & No & 86 & 43.0 \\
\hline \multirow{2}{*}{ Source of information } & Teacher (lecture) & $\mathbf{2 0 0}$ & $\mathbf{1 0 0}$ \\
\cline { 2 - 5 } & Mass media & 40 & 20.0 \\
\hline
\end{tabular}




\begin{tabular}{|l|l|l|l|}
\hline & Doctors & 8 & 4.0 \\
\hline Total & & $\mathbf{2 0 0}$ & $\mathbf{1 0 0}$ \\
\hline
\end{tabular}

Table (2) reveals that $(57 \%)$ of students receive information concerning pediatric basic life support. The mass media is the main source of information about pediatric basic life support.

Table 3:-Study sample distribution regarding knowledge items

\begin{tabular}{|c|c|c|c|c|c|}
\hline \multirow{2}{*}{ o. } & \multirow{2}{*}{ Items } & \multicolumn{2}{|c|}{ Incorrect } & \multicolumn{2}{|c|}{ Correct } \\
\hline & & req. & $\%$ & req. & $\%$ \\
\hline 1. & What does abbreviation AED stands for: Automated External Defibrillator & 7 & 85 & 03 & 51. \\
\hline 2. & $\begin{array}{l}\text { When you find a child unresponsive in the middle of the road, what will be your } \\
\text { first response? (Note: You are alone there): Look for safety }\end{array}$ & 42 & 1 & 8 & 29 \\
\hline 3. & $\begin{array}{l}\text { What are your first priorities when you find a collapsed child: The SAFE } \\
\text { approach or the DRABC approach }\end{array}$ & 46 & 3 & 4 & 527 \\
\hline 4. & $\begin{array}{l}\text { The causes of cardio respiratory arrest in children are usually the result of: } \\
\text { Hypoxia and hypovolemia }\end{array}$ & $\mathbf{0}$ & $\mathbf{0}$ & 20 & 160 \\
\hline 5. & $\begin{array}{l}\text { How do you assess responsiveness in an infant / child: Gently grasp and squeeze } \\
\text { the child's shoulders and ask loudly "are you all right?" }\end{array}$ & 33 & 6.5 & 7 & $\begin{array}{ll}33 . \\
5\end{array}$ \\
\hline 6. & $\begin{array}{l}\text { Which head position is recommended to ensure an infant has an open airway? } \\
\text { Neutral position }\end{array}$ & 48 & 4 & 2 & 26 \\
\hline 7. & $\begin{array}{l}\text { Which head position is recommended to ensure a child has an open airway? } \\
\text { Sniffing position }\end{array}$ & 33 & 6.5 & 7 & $\begin{array}{ll}33 . \\
5\end{array}$ \\
\hline 8. & Which procedure is used to open child airway? Jaw trust or head tilt and chin left & 4 & 7 & 06 & 53 \\
\hline 9. & $\begin{array}{l}\text { Why should a blind finger sweep technique to clear an airway never be used in } \\
\text { infants and children? It may cause tissue damage to the soft palate }\end{array}$ & $\mathbf{0}$ & 5 & 30 & 65 \\
\hline 10. & $\begin{array}{l}\text { Severe airway obstruction in a child who is still conscious should be managed by: } \\
\text { A series of back blows and chest thrusts }\end{array}$ & 33 & 6.5 & 7 & 33. \\
\hline 11. & $\begin{array}{l}\text { You assess that the child is not breathing, how many rescue breaths should } \\
\text { initially be given? Up to } 5 \text { breaths to ensure } 2 \text { effective breaths }\end{array}$ & 30 & 5 & $\mathbf{0}$ & 35 \\
\hline 12. & $\begin{array}{l}\text { A child with no signs of life is: Unconscious/unresponsive, not moving and not } \\
\text { breathing normally }\end{array}$ & 8 & 9 & 22 & 61 \\
\hline 13. & $\begin{array}{l}\text { If you were checking for a pulse in an infant what sites could you use? Either } \\
\text { femoral or brachial arteries }\end{array}$ & 36 & 8 & 4 & 32 \\
\hline $\begin{array}{l}1 \\
4\end{array}$ & $\begin{array}{l}\text { How long should you assess for circulation? (This includes checking for both } \\
\text { signs of life and performing a pulse check) } 10 \text { seconds }\end{array}$ & 28 & & 72 & \\
\hline $\begin{array}{l}1 \\
5\end{array}$ & $\begin{array}{l}\text { Which of the following are indications to commence cardiac compressions in } \\
\text { infants and children? All of the above }\end{array}$ & 57 & 8.5 & 43 & ${ }^{2}$ \\
\hline $\begin{array}{l}1 \\
6\end{array}$ & $\begin{array}{l}\text { If you confirm child is not responding to you even after shaking and shouting } \\
\text { at him, what will be your immediate action? Activate EMS (Emergency } \\
\text { Medical Services) }\end{array}$ & 36 & 8 & 64 & $2^{3}$ \\
\hline 1 & $\begin{array}{l}\text { What is the location for chest compression in infants or children? One finger } \\
\text { breadth below the nipple line }\end{array}$ & $25^{1}$ & 2.5 & 75 & ${ }^{3} \mathbf{5}^{3}$ \\
\hline $\begin{array}{l}1 \\
8\end{array}$ & $\begin{array}{l}\text { If you do not want to give mouth-to-mouth CPR, the following can be } \\
\text { done except: No CPR }\end{array}$ & 58 & & 42 & \\
\hline 1 & How do you give rescue breathing in infants? Mouth-to-mouth and nose & $46^{1}$ & & 54 & \\
\hline 2 & $\begin{array}{l}\text { If you are performing cardiac compressions on a child what depth do you } \\
\text { compress the chest? One-half to one-third depth of chest }\end{array}$ & 60 & & 40 & \\
\hline 2 & Rate of chest compression in children during CPR: 100 / min & 55 & 7.5 & 45 & 2.5 \\
\hline 2 & In a new born the chest compression and ventilation ratio is: $3: 1$ & $73^{1}$ & $6.5^{8}$ & 27 & 3.5 \\
\hline
\end{tabular}




\begin{tabular}{|c|c|c|c|c|c|}
\hline 2 & $\begin{array}{l}\text { How many compressions do you need to aim for to maximize cerebral } \\
\text { perfusion? } 100 \text { compressions per minute }\end{array}$ & $41^{1}$ & $0.5^{7}$ & 59 & $9.5^{2}$ \\
\hline & $\begin{array}{l}\text { It is recommended that CPR continue until: Qualified help arrives to assist; } \\
\text { exhaustion prevents you continuing and signs of life return }\end{array}$ & $36^{1}$ & & 64 & $2^{3}$ \\
\hline 2 & What is the abbreviation of "BLS": Basic Life Support & $2^{1}$ & & 74 & \\
\hline
\end{tabular}

This table indicates that most of senior nursing students responses to the items of knowledge toward pediatric basic life support are incorrect for all items, excepting items $(1,4,8,9,12)$ their responses are correct.

Table 4:-Overall assessment of senior nursing student knowledge about pediatric basic life support

\begin{tabular}{|l|l|l|l|l|}
\hline \multirow{2}{*}{ Main Domain } & Incorrect & Correct \\
\cline { 2 - 5 } & Freq. & $\mathbf{\%}$ & Freq. & $\mathbf{\%}$ \\
\hline Overall assessment of student's Knowledge & 130.44 & $\mathbf{6 5 . 2}$ & 69.56 & 34.78 \\
\hline
\end{tabular}

This table revels that overall assessment of senior nursing student knowledge regarding pediatric basic life support is incorrect.

Table 5:-Relationship between knowledge items for study group and demographic characteristics

\begin{tabular}{|c|c|c|c|c|}
\hline \multicolumn{2}{|c|}{ Demographic characteristics } & \multirow{2}{*}{$\begin{array}{l}\begin{array}{l}\text { Mean percentage of positive } \\
\text { responses }\end{array} \\
36.1\end{array}$} & \multirow{2}{*}{$\begin{array}{l}\text { SD } \\
12.06\end{array}$} & \multirow{3}{*}{\begin{tabular}{|l|} 
p- value \\
0.8553
\end{tabular}} \\
\hline \multirow[t]{3}{*}{ Age (years) } & $20-22$ & & & \\
\hline & $23-25$ & 33.4 & 16.62 & \\
\hline & $\geq 26$ & 35.3 & 22.73 & \\
\hline \multirow[t]{2}{*}{ Gender } & Male & 35.54 & 12.86 & \multirow[t]{2}{*}{0.7612} \\
\hline & Female & 34.3 & 15.76 & \\
\hline \multirow[t]{2}{*}{ Residence } & Rural & 34.39 & 12.96 & \multirow[t]{2}{*}{0.7286} \\
\hline & Urban & 35.85 & 16.32 & \\
\hline \multirow[t]{2}{*}{ Family Type } & Nuclear & 34.13 & 13.49 & \multirow[t]{2}{*}{0.7248} \\
\hline & Extended & 35.53 & 14.37 & \\
\hline
\end{tabular}

This table indicate that no- significant relationship between student's knowledge about pediatric basic life support with socio-demographic characteristic.

\section{Discussion:-}

Table 1 shows that, about (48.5\%) from participants are within age group (20-22) years. Regarding to the participant's gender, the most of them they were females. This is agreement with Mayanlambam and Devi, (2016) mentions that the age 20 years is dominant age for participant's and most of them were females. ${ }^{(8)}$ In regard to place of residence, the majority of study sample were living in rural areas. This result is approving with Mayanlambam and Devi, (2016) reported that the most of study sample living in rural areas. ${ }^{(8)}$ Concerning to family type, the highest percentage from them live with nuclear family

According to the results show in (Table 2) BLS involve care providing to patients suffering from cardiac arrest, respiratory obstruction or arrest by healthcare provider and public safety professional individuals. Actually, clearing of obstructive airway was firstly done, subsequently cardiopulmonary resuscitation, and finally an automated external defibrillator to perform. So everyone should master the basic steps in basic life support (ARC, 2015). ${ }^{(\mathbf{8})}$ The study results reveal that more than half of the studied sample received information regarding pediatric BLS; the mass media is the main source for information.

In (tables 3 and 4) indicate that the students have poor knowledge about pediatric basic life support. This agreement with Thomas, (2010) reported that the basic life support among students in nursing colleges is poor knowledge.(1)

In (table 5) the study result indicates that no- significant association between student's knowledge regarding pediatric basic life support and socio-demographic data. 


\section{Conclusions:-}

The result of this study indicated that the mass media is main source of student knowledge about pediatric basic life support, majority of participants have poor knowledge about pediatric basic life support and Finally, there is nosignificant association between senior nursing students knowledge about pediatric basic life support with sociodemographic data.

\section{Declaration of Interest:}

Nil.

\section{Source of Funding:}

Self.

\section{Ethical Clearance:}

After the approval from faculty of nursing, university of kufa/Iraq and another permission obtained from nursing colleges in the Middle Euphrates before enrollment.

\section{References:-}

1. Thomas, G.: a study to assess the effectiveness of video assisted teaching on knowledge regarding basic life support in paediatric emergencies among third year Gnm students in selected nursing schools Bangalore, Oriental College of Nursing, Dissertation, 2010.

2. Hazinski, M. F., \& Field, J. M. (2010). 2010 American Heart Association guidelines for CPR and emergency cardiovascular care science. Circulation, 122(Suppl), S639-S946

3. Maconochie I, Bingham R, Eich C, et al. European Resuscitation Council Guidelines for Resuscitation Section 6 Pediatric Life Support. Resuscitation, 2015; 95:222-47.

4. Rescuers, A.: Highlights of the American Heart Association Guidelines for CPR and ECC, 2010.

5. American Heart Association (AHA) guidelines for cardiopulmonary resuscitation (CPR) and emergency cardiovascular care (ECC) of pediatric and neonatal patients: pediatric basic life support. Pediatrics, 2006, 117(5), e 989-e 1004

6. American Red Cross, Basic Life Support for Healthcare Providers Handbook, 2015, United States of America, 12.

7. Almesned A.; Almeman A.; Alakhtar, A.; AlAboudi, A.; Alotaibi, A.; Al-Ghasham, Y.; \&Aldamegh, M.: Basic life support knowledge of healthcare students and professionals in the Qassim University. International journal of health sciences, 2014. 8(2), p.p: 141.

8. Mayanlambam P. \& Devi A.: Knowledge and Practice Regarding Basic Life Support among Nursing Students, International Journal of Research \& Review, 2016,3(1),P.P.: 43-47. 